\title{
Antinociceptive activity of some Bangladeshi medicinal plant extracts
}

\author{
SJ Uddin ${ }^{1, *}$, JA Shilpi ${ }^{1}$, R Rouf ${ }^{1}$, MM Ferdous ${ }^{2}$, L Nahar ${ }^{3}$ and SD Sarker ${ }^{4}$ \\ ${ }^{1}$ Pharmacy Discipline, Life Science School, Khulna University, Khulna-9208, Bangladesh; ${ }^{2}$ Department of Botany, \\ University of Rajshahi, Rajshahi-6205, Bangladesh; ${ }^{3}$ School of Life Sciences, The Robert Gordon University, St \\ Andrew Street, Aberdeen AB25 1HG, Scotland, UK; ${ }^{4}$ Pharmaceutical Biotechnology Research Group, School of \\ Biomedical Sciences, University of Ulster at Coleraine, Cromore Road, Coleraine BT52 1SA, Co. Londonderry, \\ Northern Ireland, UK
}

\section{SUMMARY}

The extracts of some Bangladeshi medicinal plants, Possur (Xylocarpus mekongensis), Dhundul (Xylocarpus granatum), Gab (Diospyros peregrina), Kadom (Anthocephalus chinensis) and Sundari (Heritiera fomes), were assessed for their possible antinociceptive activity using acetic acid induced writhing model in mice. Most of these plants have been used in traditional medicine in Bangladesh as well as in other countries for the treatment of various ailments ranging from common cold to cancer. All these extracts significantly inhibited the acetic acid induced writhing in mice at the oral dose of $500 \mathrm{mg} / \mathrm{kg}$ body weight. The extract of Anthocephalus chinensis bark showed the most potent writhing inhibition $(69.47 \%, P<0.001)$ and that of Diospyros peregrina bark had the least $(33.54 \%, P<0.02)$.

Key words: Meliaceae; Ebenaceae; Rubiaceae; Sterculiaceae; Antinociceptive activity

\section{INTRODUCTION}

Xylocarpus (X.) mekongensis (Lamk.) M. Roem. (Syn: $X$. moluccensis, Carapa moluccensis) (Meliaceae), commonly known as 'Possur', is a glabrous, medium-sized tree found in littoral forests of Bengal, Burma, the Andaman's, the Malay Peninsula and Archipelago, Australia, Fiji and Africa. In Bangladesh, this species grows in the north tract, remote from the sea, chiefly in low lying swampy locality, of the Sundarbans, the largest mangrove forest in the world (Kiritikar and Basu, 1999; GRIN database, 2005). Xylocarpus (X.) granatum J. König (Meliaceae), known as 'dhundul', both $X$. granatum and X. mekongensis are also well

*Correspondence: SJ Uddin, Pharmacy Discipline, Life Science School, Khulna University, Khulna-9208, Bangladesh. Tel: +880 41 720171-3; Fax: +880 41 731244; E-mail: uddinsj@yahoo.com distributed in a number of other countries of southeast Asia, Australia and east Africa (Tomlinson, 1986). Diospyros (D.) peregrina Gurke (Ebenaceae), Bengali name ' $\mathrm{gab}$ ', is a medium-sized evergreen tree indigenous to Bangladesh and India, and also found in many other countries of Asia and America (Ghani, 1998; GRIN database, 2005). Anthocephalus (A.) chinensis (Lamk.) Rich. Ex Walp. (Rubiaceae), commonly known as 'kadam', is a medium-sized deciduous tree that grows in the sub-Himalayan tract at latitudes from $9^{\circ} \mathrm{S}$ to $27^{\circ} \mathrm{N}$, from Nepal eastward to Bangladesh, India, Myanmar, Sri Lanka, Indonesia, the Phillippines and Papua New Guinea (Whitmore, 1984; Kirtikar and Basu, 1999; $A R C B C$ database, 2004; GRIN database, 2005). The Sundarbans, the largest single tract of mangrove forests in the world and the habitat for the tree species, Heritiera (H.) fomes Buch.-Ham. (Sterculiaceae), common name 'sundari' (Rahman, 2000). 
The traditional medicinal and non-medicinal uses of X. mekongensis include its use as an astringent and febrifuge, for the treatment of dysentery and diarrhoea, and in boat-building and furniture (Ghani, 1998). X. granatum has been used traditionally to treat diarrhoea, cholera and fever, and as an astringent and emolient (ARCBC databases, 2004; Phytochemical and Ethnobotanical databases, 2005). It is also used in boat-building, and as furniture wood and fuel-wood. The barks of this plant are used for tanning and for the preparation of dyes of umber colour. The aqueous extract of different parts of this plant was also reported to have significant antifilarial activity (Wan Omar et al., 1997; Zaridah et al., 2001). $D$. pregerina has traditionally been used as an aphthaee, aphrodisiac, astringent, bactericide and tonic, and for the treatment of many ailments, e.g. diarrhoea, cholera, dysentery, fever, malaria, menorrhagia and sore throat (Singh et al., 1988; Kirtikar and Basu, 1999; Phytochemical and Ethnobotanical databases, 2005). It has also been used to treat snake-bites (Kirtikar and Basu, 1933). The water extract of the ' $\mathrm{gab}$ ' fruits is used as a dye for fishing nets and boats. Singh et al. (1988) reported the anti-stress activity of an EtOAc extract of the whole plant of $D$. peregrina, which was similar to Panax ginseng. The alcoholic extract of stem barks of this plant has been reported to have hypoglycemic, diuretic and anti-cancer properties (Ghani, 1998). The ethnobotanical and traditional medicinal uses of $A$. chinensis include its use as a remedy for fever, chest congestion and stomatitis, and as an astringent and tonic (Yusuf et al., 1994; ARCBC database, 2004; Phytochemical and Ethnobotanical Databases, 2005). It is also used in snakebites. However, its major economical importance lies in its application as a source of wood for matchstick boxes, tea boxes, bobbins, veneer, plywood, crates and furniture (Grijpma, 1967). The logs are used for dugout canoes, roof structure and light construction. While there is no proven recorded for any medicinal use value of $H$. fomes. It is used extensively as cottage poles, pillars, piles and fuel woods.

A number of limonoids (Connolly et al., 1976; Taylor, 1983; Khisal et al., 1991; Kokpol et al., 1996; Wu et al., 2003, 2004) and sterols (Hogg and Gillian, 1984) were reported from $X$. granatum and $X$. mekongensis. An aliphatic ketol, onadecan-7-ol-2one and triterpenes were isolated from the stem, fruits and seeds of D. peregrina (Misra et al., 1971; Chauhan and Kumari, 1980; Jain and Yadav, 1994). The fruits and roots of this plant were also found to produce flavonoids (Chauhan et al., 1982; Jain and Yadava, 1997). Secoiridoid glucosides and phenolic glycosides (Kitagawa et al., 1996) and quinoline alkaloids (Handa et al., 1983, 1984) were isolated from the bark of $A$. chinensis.

As part of our on-going pharmacological screening of random selected Bangladeshi medicinal plants (Shilpi et al., 2004; Uddin et al., 2004, 2005), we now report on the investigation whether $X$. mekongensis, $X$. granatum, D. peregrina, $A$. chinensis, and $H$. fomes have any effect on the nociceptive response in mice.

\section{MATERIALS AND METHODS}

\section{Plant material and extraction}

Plant parts of X. mekongensis, X. granatum, D. peregrina, A. chinensis, and $H$. fomes were collected from the tidal forest in the coastal Sundarbans (a swamp region in the Ganges delta) or other places in the district of Khulna (Table 1), and identified by experts of the Bangladesh National Herbarium, Dhaka, Bangladesh. Voucher specimens (Table 1) representing these collections have been deposited in the Bangladesh National Herbarium, Dhaka, Bangladesh.

\section{Extraction}

Shade-dried and ground plant parts (100 - $250 \mathrm{~g})$ (Table 1) were extracted by maceration over $24-72$ $h$ using methanol $(\mathrm{MeOH})$ and ethanol $(\mathrm{EtOH})$ (Table 1) at room temperature. The extracts were 
Table 1. Collection details and \% of writhing inhibition of X. mekongensis, X. granatum, D. peregrina, A. chinensis, and $H$. fomes

\begin{tabular}{|c|c|c|c|c|c|c|c|c|}
\hline \multirow[b]{2}{*}{$\begin{array}{l}\text { Botanical names } \\
\text { (Family) }\end{array}$} & \multirow{2}{*}{$\begin{array}{c}\text { Common } \\
\text { Bengali } \\
\text { names }\end{array}$} & \multicolumn{4}{|c|}{ Collection details } & \multirow[b]{2}{*}{$\begin{array}{l}\text { Extract } \\
\text { used }\end{array}$} & \multirow[b]{2}{*}{$\begin{array}{l}\text { Yields } \\
(\%)\end{array}$} & \multirow{2}{*}{$\begin{array}{l}\% \text { Of writh- } \\
\text { ing inhibition } \\
(P \text { value })\end{array}$} \\
\hline & & $\begin{array}{l}\text { Plant parts } \\
\text { Used (code) }\end{array}$ & Place & Date & $\begin{array}{l}\text { Voucher } \\
\text { Number }\end{array}$ & & & \\
\hline \multirow{2}{*}{$\begin{array}{l}\text { X. mekongensis } \\
\text { (Meliaceae) }\end{array}$} & \multirow{2}{*}{ Possur } & Bark (MPB) & \multirow{2}{*}{$\begin{array}{l}\text { The Sundarbans, } \\
\text { Khulna, } \\
\text { Bangladesh }\end{array}$} & \multirow{2}{*}{$\begin{array}{l}\text { Aúgúst } \\
2003\end{array}$} & \multirow{2}{*}{$\begin{array}{c}\text { DACB } \\
30320\end{array}$} & $\mathrm{MeOH}$ & $32.0 \%$ & $\begin{array}{c}58.69 \\
(P<0.001)\end{array}$ \\
\hline & & $\begin{array}{c}\text { Pneumatophore } \\
\text { (MPR) }\end{array}$ & & & & $\mathrm{MeOH}$ & $18.46 \%$ & $\begin{array}{c}44.92 \\
(P<0.01) \\
\end{array}$ \\
\hline $\begin{array}{l}\text { X. granatum } \\
\text { (Meliaceae) }\end{array}$ & Dhundul & Bark (MDB) & $\begin{array}{c}\text { The Sundarbans, } \\
\text { Khulna, } \\
\text { Bangladesh }\end{array}$ & $\begin{array}{l}\text { August } \\
2003\end{array}$ & $\begin{array}{l}\text { DACB } \\
12789\end{array}$ & $\mathrm{MeOH}$ & $20 \%$ & $\begin{array}{c}52.70 \\
(P<0.001)\end{array}$ \\
\hline $\begin{array}{l}\text { D. peregrine } \\
\text { (Ebenaceae) }\end{array}$ & $\mathrm{Gab}$ & Bark (MGB) & $\begin{array}{l}\text { South Khalish- } \\
\text { pur, Khulna, } \\
\text { Bangladesh }\end{array}$ & $\begin{array}{l}\text { July } \\
2003\end{array}$ & $\begin{array}{l}\text { DACB } \\
30323\end{array}$ & $\mathrm{MeOH}$ & $12.0 \%$ & $\begin{array}{c}33.54 \\
(P<0.02)\end{array}$ \\
\hline \multirow{2}{*}{$\begin{array}{l}\text { A. chinensis } \\
\text { (Rubiaceae) }\end{array}$} & \multirow{2}{*}{ Kadam } & Leaves (MKL) & \multirow{2}{*}{$\begin{array}{c}\text { Shaikpara, } \\
\text { Khulna, Bang- } \\
\text { ladesh }\end{array}$} & \multirow{2}{*}{$\begin{array}{l}\text { October } \\
2003\end{array}$} & \multirow{2}{*}{$\begin{array}{l}\text { DACB } \\
30321\end{array}$} & $\mathrm{MeOH}$ & $8.0 \%$ & $\begin{array}{c}50.90 \\
(P<0.01) \\
\end{array}$ \\
\hline & & Bark (MKB) & & & & $\mathrm{MeOH}$ & $10.71 \%$ & $\begin{array}{c}69.47 \\
(P<0.001)\end{array}$ \\
\hline $\begin{array}{l}\text { H. fomes } \\
\text { (Sterculiaceae) }\end{array}$ & Sundari & Bark (ESB) & $\begin{array}{l}\text { The Sundar- } \\
\text { bans, Khulna, } \\
\text { Bangladesh }\end{array}$ & $\begin{array}{l}\text { August } \\
2003\end{array}$ & $\begin{array}{l}\text { DACB } \\
30324\end{array}$ & $\mathrm{EtOH}$ & $20 \%$ & $\begin{array}{c}59.89 \\
(P<0.001)\end{array}$ \\
\hline
\end{tabular}

filtered and dried using a rotary evaporator at a temperature not exceeding $55^{\circ} \mathrm{C}$ and the yields are mentioned in the Table 1.

\section{Animals}

Swiss albino mice of either sex (20 - $25 \mathrm{~g})$ were obtained from the Animal house, Pharmacy Discipline, Khulna University, Khulna. The animals were housed under standard laboratory conditions (relative humidity 55 - 65\%, room temperature $23.0 \pm 2.0^{\circ} \mathrm{C}$ and $12 \mathrm{~h}$ light: dark cycle). The animals were fed with standard diet and water ad libitum.

\section{Antinociceptive activity study using acetic acid induced writhing assay}

The method of Koster et al. (1959) was adopted with minor modification. The animals were orally fed with the extracts, vehicles (for control groups) at the specified doses ( $500 \mathrm{mg} / \mathrm{kg}$ body weight). Thirty minutes after administration of the extract and the vehicle, each animal was given $0.7 \%(\mathrm{v} / \mathrm{v})$ solution of acetic acid $(0.1 \mathrm{ml} / 10 \mathrm{~g}$ body weight) interperitoneally (i.p.) to induce abdominal contractions or writhing. Five minutes after the administration of acetic acid, the number of writhing for each animal was counted for $15 \mathrm{~min}$. The number of writhings in the control was taken as $100 \%$ and percent inhibition was calculated as follows:

$\%$ Inhibition of writhing $=100-$ (treated mean $/$ control mean) $\times 100$

For comparison, the same experiment was carried out with a positive control group treated orally with Paracetamol (Square Pharmaceuticals Ltd., Bangladesh) at the dose of $50-\mathrm{mg} / \mathrm{kg}$ body weights.

\section{RESULTS}

In the acetic acid induced writhing test all the extracts significantly suppressed the frequency of acetic acid induced writhing in mice (\% of writhing inhibition values range within $33.54 \%$ to $69.47 \%$ ) (Fig. 1). Among the extracts, the ethanolic extract 


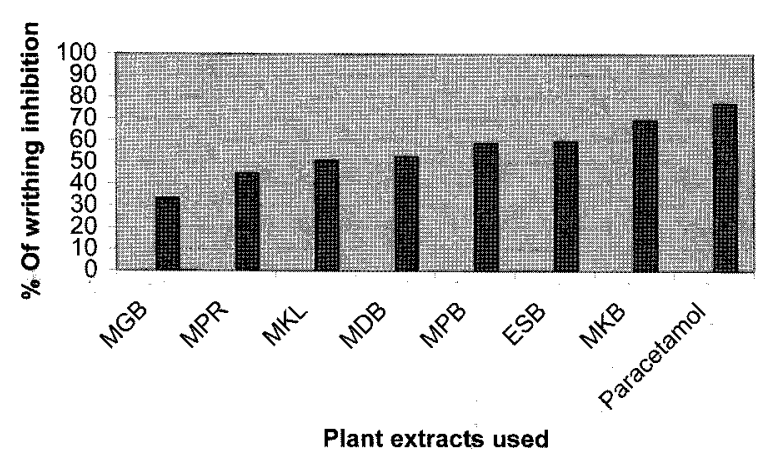

Fig. 1. Comparative \% of writhing inhibition of the extracts in acetic acid induced writhing in mice.

of A. chinensis bark showed the most potent antinociceptive activity (69.47\% writhing inhibition, $P<0.001)$ whereas the methanolic extract of $D$. peregrina bark showed the least $(33.54 \%$ writhing inhibition, $P<0.02$ ) (Table 2). Paracetamol, used as the positive control exhibited a writhing inhibition of $77.25 \%$ as compared to control and the result was statistically significant $(P<0.001)$.

\section{DISCUSSION}

An analgesic selectively relives pain by acting on the central nervous system (CNS) or on peripheral pain mechanism, without significantly altering consciousness. Acetic acid is a pain stimulus and interperitoneal (i.p.) administration of acetic acid $(0.7 \%)$ causes localized inflammation, which causes contraction of the body in mice and referred to as 'writhing'. Such pain stimulus causes the release of free arachidonic acid from tissue phospholipid by the action of phospholipase $\mathrm{A}_{2}$ and other acyl hydrolases.

There are three major pathways in the synthesis of the eicosanoids from arachidonic acid. All the eicosanoids with ring structures that is the prostaglandins, thromboxanes and prostacyclines are synthesized via the cyclooxygenase pathway. The leucotrienes, HETEs (hydroxyeicosatetraenoic acids), and HPETEs (hydroperoxyeicosatetraenoic acids) are hydroxylated derivatives of straightchain fatty acid and are synthesized via the lipooxygenase pathway (Mary et al., 1997).

The prostaglandins, mainly prostacyclin $\left(\mathrm{PGI}_{2}\right)$ and prostaglandin-E have been reported to be responsible for pain sensation by exciting the Afibres. Activity in the A-fibres cause a sensation of sharp well localized pain (Rang, 1993). Any agent that lowers the number of writhing will demonstrate analgesia preferably by inhibition of prostaglandin synthesis, a peripheral mechanism of pain inhibition.

These extracts possess free radical scavenging activity (Uddin et al., 2004), and it is now well

Table 2. Effect of X. mekongensis, X. granatum, D. peregrina, A. chinensis, and H. fomes extracts on acetic acid induced writhing in mice

\begin{tabular}{|c|c|c|c|c|}
\hline \multicolumn{2}{|l|}{ Treatment } & $\operatorname{Dose}^{a}$ (mg/kg,p.o.) & Writhings $^{b}$ & Inhibition (\%) \\
\hline \multicolumn{2}{|c|}{ Control (1\% Tween $80,10 \mathrm{ml} / \mathrm{kg}$,p.o.) } & - & $33.40 \pm 1.04$ & - \\
\hline \multicolumn{2}{|c|}{ Paracetamol } & 50 & $7.6 \pm 0.57^{* \star *}$ & 77.25 \\
\hline \multirow[t]{2}{*}{ X. mekongensis } & Bark & 500 & $13.8 \pm 1.56^{\star * *}$ & 58.69 \\
\hline & pneumatophore & 500 & $18.4 \pm 2.93^{* *}$ & 44.92 \\
\hline X. granatum & bark & 500 & $15.8 \pm 1.64^{* * *}$ & 52.7 \\
\hline D. peregrina & bark & 500 & $22.2 \pm 3.25^{\star}$ & 33.54 \\
\hline \multirow[t]{2}{*}{ A. chinensis } & bark & 500 & $10.2 \pm 0.96^{* \star *}$ & 69.47 \\
\hline & leaf & 500 & $16.4 \pm 3.29^{2 *}$ & 50.90 \\
\hline H. fomes & bark & 500 & $13.4 \pm 1.44^{\star \star \star \star}$ & 59.89 \\
\hline
\end{tabular}

${ }^{a}$ Administered $45 \mathrm{~min}$ before $0.7 \%$ acetic acid administration $\left(\mathrm{ml} / \mathrm{kg}\right.$,i.p.). ${ }^{\mathrm{b}}$ Counted for $15 \mathrm{~min}$, starting $5 \mathrm{~min}$ after acetic acid administration; values are mean \pm S.E. ${ }^{*} P<0.02$; $P<0.01{ }^{* * * *} P<0.001$ vs. control, Student's $t$-test; $\mathrm{n}=5$. 
established that free radicals (superoxide, hydroxyl radical, nitric oxide) and other reactive species (hydrogen peroxide, single oxygen, perxynitrite, hypochlorous acid) contribute to the pathology of many disorders including atherogenesis, neurodegeneration, chronic inflammation, and function of the immune system (Hemani and Panihar, 1998). Recent studies suggest that the inflammatory tissue damage is due to the liberation of reactive oxygen species form phagocytes invading the inflammation sites (Winrow et al, 1993; Conner and Grisham, 1996; Parke and Sapota, 1996). Many natural and synthetic antioxidants are in use to prevent the lipid peroxidation. Search for new antioxidant remains a highly research area because the antioxidants play a very important role in reducing the risk of various chronic disorder. So it can be assumed that their antioxidant activity may reduce the production of free arachidonic acid from phospholipid or may inhibit the enzyme system, which is responsible for the synthesis of prostaglandins, and ultimately relive pain-sensation.

\section{CONCLUSION}

From the reference of our previous antioxidant study of these extracts and the results obtained in the present study, it can be postulated that the antinociceptive activity of the extracts may be linked to their free radical scavenging activity. However, further study could be carried out to find the actual mechanism of their antinociceptive activity and to isolate the active principle(s) responsible for such activity.

\section{REFERENCES}

ARCBC database. (2004) ASEAN Regional Centre for Biodiversity Conservation, The Phillippines. Available on-line at. http://www.arcbc.org/arcbcweb/medicinal_ plants/efault.htm.

Connolly JD, MacLellan M, Okorie DA, Taylor DAH. (1976) Limonoids from Xylocarpus molucensis (Lam.) M. Roem. J. Chem. Soc. 1, 1993-1996.
Chauhan JS, Kumari G. (1980) Nonadecan-7-ol-2-one an aliphatic ketol from Doiospyros peregrina. Phytochemistry 19, 2637-2638.

Conner EM and Grisham MS. (1996) Inflammation, Free radicals and antioxidants. Nutrition 12, 274279.

Grijpma P. (1967) Anthocephalus cadama, a versatile, fast-growing industrial tree species for the tropics. Turrialba 17, 321-328.

GRIN database. (2005) USDA, ARS, National Genetic Resources Program, Germplasm Resources Information Network-(GRIN), National Germplasm Resources Laboratory, Beltsville, Maryland, USA. Available on-line at: http://www.ars-grin.gov/.

Ghani A. (1998) Medicinal Plants of Bangladesh. Asiatic Society of Bangladesh, Dhaka.

Gupta BD, Dandiya PC, Gupta ML. (1971) A psychopharmacological analysis of behavior in rat. Jpn. J. Pharmacol. 21, 293.

Handa SS, Gupta SK, Vasisht K, Keene AT, Phillipson JD. (1983) Quinoline alkaloids from Anthicephalus chinensis. Planta Med. 50, 358-358.

Hemani T, Panihar MS. (1998) Reactive oxygen species and oxidative property of Nardostachys jatamanasi. Indian J. Expt. Biol. 34, 1150-1151.

Hogg RW, Gillian FT. (1984) Fatty acids, sterols and hydrocarbons in the leaves from eleven species of mangrove. Phytochemistry 23, 93-97.

Handa SS, Borris RP, Cordell GA, Phillipson JD. (1984) NMR spectral analysis of cadambine from Anthicephalus chinensis. J. Nat. Prod. 46, 325-330.

Jain N, Yadav RN. (1997) Furano- $\left(2^{\prime \prime}, 3^{\prime \prime}, 7,8\right)-3^{\prime}, 5^{\prime}-$ dimethoxy-5- hydroxyflavone: A new furanoflavone from the fruits of Diospyros peregrina Gurke. Asian J. Chem. 9, 442-444.

Jain N, Yadav RN. (1994) Peregrinol, a lupane type triterpene from the fruits of Diospyros peregrina. Phytochemistry. 35, 1070-1072.

Khisal AA, Crews P, Aalbersberg B, Prasad R. (1991) Limonoids from the Fijian medicinal plant dabi (Xylocarpus granatum). Tetrahedron 47, 8943-8948.

Kirtikar KR, Basu BD. (1933) Indian Medicinal Plant, Allahabad, India.

Kiritikar KR, Basu BD. (1999) Indian Medicinal Plants, $2^{\text {nd }}$ edition, Allahabad, India.

Kitagawa I, Wei H, Nagao S, Mahmud T, Hori K, Kobayashi M, Uji T, Shibuya H. (1996) Indonesian medicinal plants. 14. Characterisation of 3'-O- 
caffeoylsweroside, a new secoiridoid glucoside and kelampayosides $\mathrm{A}$ and $\mathrm{B}$, two new phenolic Apioglucosides, from the bark of Anthocephalus chinensis (Rubiaceae). Chem. Pharm. Bull. 44, 11621167.

Koster R, Anderson M, Beer EJ. (1959) Acetic acid for analgesic screening. Fed. Proc. 18, 412-415.

Mary JM, Richard AH, Pamela CC. (1997) Lippincott's Illustrated Reviews of Pharmacology, $2^{\text {nd }}$ edition, Lippincott-Raven Publishers, Philadelphia, USA.

Misra PS, Misra G, Nigam SK, Mitra CR. (1971) Constituents of Diospyros peregrina fruit and seed. Phytochemistry 10, 904-905.

Parke DV, Sapota A. (1996), Chemical toxicity and reactive species. Int. J. Occup. Med. Envirn. Health 9, 119-123.

Phytochemical and Ethnobotanical databases. (2005) USDA, ARS, Beltsville Agricultural Research Center, Beltsville, Maryland, USA, Available online at: http://www.ars-grin.gov/duke/.

Rahman LM. (2000) The Sundarbans: A unique wilderness of the world. USDA Forest Service Proceedings RMPRS-P-15 2, 143-148.

Rang HP, Dale MM. (1993) Pharmacology, pp. 706-711, $2^{\text {nd }}$ edition, Churchill Livingstone publisher, UK.

Singh N, Nath R, Gupta ML. (1988) A pharmacological evaluation of antistress activity of Diospyros peregrina Gurke. Indian J. Pharmacol. 20, 102-108.

Shilpi SJ, Uddin SJ, Rouf R, Billah MM. (2004), Central nervous system depressant activity of Diospyros peregrina bark, Orient. Pharm. Exp. Med. 4, 249-252.

Taylor DAH. (1983) Limonoids extraction from Xylocarpus molucensis. Phytochemistry 22, 1297-1299.

Tomlinson PB. (1986) The Botany of Mangroves, Cambridge University Press, New York.
Uddin SJ, Shilpi JA, Alam SMS, Alamgir M, Rahman MT, Sarker SD. (2005) Antidiarrhoeal activity of the methanol extract of the barks of Xylocarpus molucensis in castor oil and magnesium sulphate-induced diarrhoea models in mice. J. Ethnopharmacol. 101, 139-143.

Uddin SJ, Shilpi JA, Barua J, Rouf R. (2005) Antinociceptive activity of Ceriops decandra leaf and pneumatophore, Fitoterapia 76, 261-263.

Uddin SJ, Shilpi JA, Delazar A, Nahar L, Sarker SD. (2004) Free radical scavenging activity of some Bangladeshi plant extracts, Orient. Pharm. Exp. Med. 4, 185-193.

Wan-Omar A, Ibrahim J, Sulaiman O, Hashim Y. (1997) Screening of local plants for antifilarial activity against adult worm and microfilariae of Brugia pahangi. J. Tropical Forest Products 3, 216-219.

Whitmore TC. (1984) A vegetation map of Malesia at scale 1-5 million. J. Biogeography 11, 461-471.

Winrow VR, Winyard PG, Morris CT, and Black DR. (1993) Free radicals in inflammation: Second messengers and mediators of tissue destruction. $\mathrm{Br}$. Med. Bull. 49, 506-540.

Wu J, Zhang S, Xiao Q, Li Q, Huang J, Long L, Huang L. (2004) Xyloccensin L, a novel limonoid from Xylocarpus granatum. Tetrahedron Lett. 45, 591-593.

Yusuf M, Chowdhury JU, Wahab MA, Begum J. (1994) Medicinal Plants of Bangladesh, Bangladesh Council of Scientific and Industrial Research, Dhaka, Bangladesh.

Zaridah MZ, Idid SZ, Wan-Omar A, Khozirah S. (2001) In vitro antifilarial effects of three plant species against adult worms of subperiodic Brugia malayi. J. Ethnopharmacol. 78, 79-84. 